
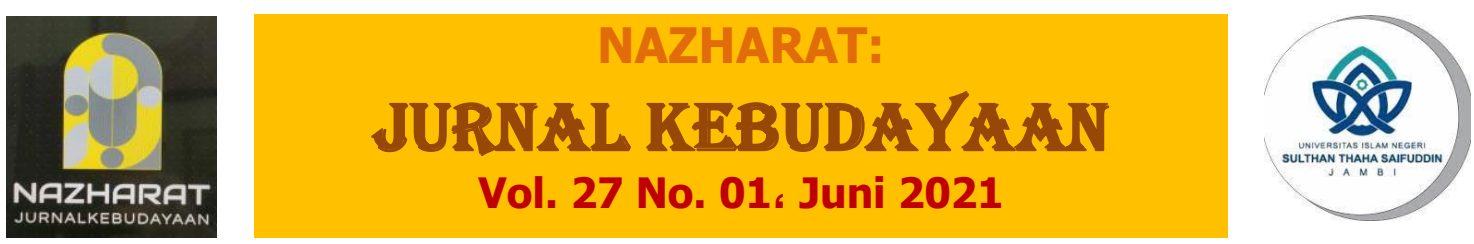

The Qur'anic Learning Software in Digital Era: A Threat towards the Value of Qur'anic Ortodoxy in Indonesia

\author{
Hamdi Putra Ahmad \\ Universitas Islam Negeri Sunan Kalijaga Yogyakarta \\ hamdiputraahmad@gmail.com
}

The gadget's software applications nowadays appear to be highly popular and its use has been elevating among gadget users. This kind of technological advance also touched the Qur'anic learning process in Indonesia. On the one hand, not only does the emergence of Qur'anic learning software stimulate children's interest, but it also provides a lot of features that will make children quickly understand and practice the Qur'anic reciting. On the other hand, this kind of learning method can threat the value of Qur'anic orthodoxy which had been applied among traditional Muslim societies since the emergence of Islam in Indonesia. Some resources have noted that there were some sacred values and courtesies perpetuated by traditional Muslims while teaching Qur'anic reciting. This article will track the historical journey of Qur'anic learnings in Indonesia and discuss how the emergence of Qur'anic Learning software (as the logical consequence of technological improvement) can threat the existence of some ancient orthodoxies toward the Qur'an.
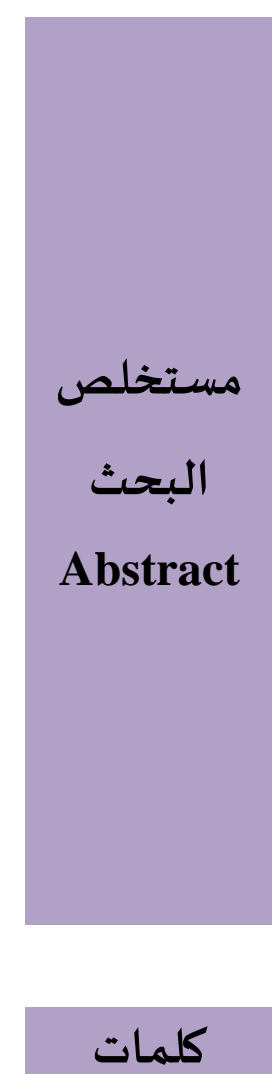

Keywords : Qur'anic learning, software, orthodoxy, sacred values

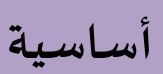

Keyword

\title{
INTRODUCTION (مقدمة)
}

The rapid exhibition of technology in this contemporary era has made all aspects of human life quickly evolve, including the Qur'an learning method. Previously, Indonesian people tended to apply methods that prioritized interaction between teachers and students, or commonly known as watonan and sorogan (Dhofier, 1985). This Qur'anic learning method has basically supported the components of the general 
learning system, such as teachers, students, learning objectives, learning environment, learning resources, and learning outcomes (Sanjaya, 2010). However, the fundamental difference between learning the Qur'an and learning the other sciences is about the value of "orthodoxy" it contains. Orthodoxy can be interpreted as a belief or a set of beliefs that regarded by certain community as the only truth, which even in the social order, the power of orthodoxy can cause people who violate it to be punished (Ahmed, 2017). In traditional al-Qur'an learning, people believe that the Qur'an is a sacred book, which in studying it, they must pay attention to a number of values, manners, and rules that must be obeyed (Nawawi, 1996). All forms of deviation from the value of manners (orthodoxy) can be considered as a violation. On the other hand, the method of learning the Qur'an in the digital era experienced many developments, even changes. One of them is the emergence of a number of gadget-based digital applications that allow users to learn the Qur'an by themselves without any guidance of a teacher.

Qur'anic learning method developed in the digital age is very important to be studied in depth. The reason is that current technological developments have helped to stimulate people's interest to learn the Qur'an, both from children and adults. One very popular trend now is the proliferation of software-based Qur'anic learning applications on Play Store, which can be accessed by almost all people who have smartphones. Nevertheless, the transition of the method of learning the Qur'an to digitalization is possible to provide a "threat" towards the values of orthodoxy in the transfer of knowledge that exists between a teacher and student due to a system that emphasized a self-taught learning. In addition, the dimension of the sacredness of the Qur'an which has always been maintained by teachers and students in formal institutions is questionable for its existence when associated with digital-based learning of the Qur'an.

This fact provokes me to conduct a research on what aspects appearing in the Qur'an learning software (particularly gadgets) which attract the attention of many modern-Muslim communities in Indonesia. In this case, I will analyze two sample applications of Qur'anic learning software with the highest number of downloads in Play Store. The first application is called "Marbel Belajar Mengaji" and the second one is called "Belajar Mengaji Al-Qur'an". Both of these applications have got the most downloads among the other Qur'anic learning applications, each of which has been downloaded more than one million downloads. Departing from these two applications, 
this study will then review the implications of the presence of Qur'anic learning software in Indonesia for the continuity of orthodoxy learning of the Qur'an that was previously held and preserved by Indonesian traditional community in descendinghereditary.

\section{HISTORY OF QUR'ANIC LEARNING IN INDONESIA: A DISTORTION OF ORTHODOXY}

The emergence of Qur'an reading and writing learning in Indonesian society in this modern era is not far from the emergence of Islam in Indonesia before the 15th century. The position of the Qur'an as the central axis in Islam, has made people feel the need to interact directly with the Qur'an, at least to be able to read it. The Qur'anic learning activity at this time was known as ngaji, and usually carried out in langgar or surau (Azra, 1999) after Maghrib prayer (Barir, 2017). Students (mostly children and adolescents) walked out of their homes to the mosque carrying the Qur'an (mus\}h\}af) by hugging it on their chests. When the teacher reads the hija > 'iyyah letters in front of his students, they will follow what the teacher says, including the tone, rhythm, and lip movements. The interaction between teacher and student at this time was very strong. And this kind of learning model was adopted from the Persian-style of Qur'anic learning system (Barir, 2017).

The presence of pesantren in the 15th century contributed to the introduction of Qur'anic reading and writing learning in the community, particularly in Java Island. Mujamal Qomar said that the presence of pesantren in the 15th century as the only institution of education owned by indigenous people has contributed in shaping literacy and culture. One application of these goals is to teach the society how to read the Qur'an correctly, which at the same time opens the door to introduce religious knowledge (Qomar, 2002). So, the people in the villages at this tima did not only learn the Qur'an in langgar or surau, but had started to switch to pesantren.

For people in some regions who were not familiar with the tradition of pesantren-based learning, the Qur'anic learning activity was done by visiting village leaders who are considered having qualification in religious knowledge. Before the 20th century, village communities in parts of Kalimantan, Sulawesi and Lombok usually 
asked pilgrims or traders from Arabia to stop at their village for a while to teach them about religion knowledge and how to read the Qur'an (Hasanah, 2015). Zamakhsyari Dhofier mentioned (as cited by Islah Gusmian) that the system of Qur'anic learning in some parts of Java Island in the 1847s was carried out in a place called Nggon Ngaji, which means the place where students read the Qur'an. The Dutch government noted that there were 1,853 of nggon ngaji with a total of 16,566 students spread across various districts on Java Island (Gusmian, 2012). Meanwhile, in parts of Sumatera (especially Minangkabau), learning the Qur'an in the villages was still consistent in implementing the Surau-based Education system. It was known from the Dutch report that there was almost no village in Minangkabau until 1869 which did not have a surau. In fact, there are at least 15 large surau in Minangkabau which were still exist as a central religious education in the first half of the 19th century (Azra, 1919).

Towards the 20th century, the system of Qur'anic learning in Indonesia experienced growth. There was a "trend" of uniformity of methods enabled students to more quickly and effectively learn the Qur'anic reading. It was noted that the bagda>diyyah was the first method appeared and was most widely applied by teachers who taught the Qur'an in Indonesia. Beside of its popularity in various countries, the survival of the bagda>diyyah method in Indonesia is due to its ability to create good interactions between teachers and students. In this method, the teachers were more active than the students since they had to read each hija> iyyah letters and then followed by the students.

Entering the 20th century, a new method emerged which was allegedly the result of the development of the bagda>diyyah method, iqro'. This method was formulated by As'ad Humam as a response to the decreasing interest of students when learning by the bagda > diyah method (Muhammedi, 2018). The method which consists of 6 volumes of this book has become a popular learning method used in various Al-Qur'an Education institutions in Indonesia (such as TK al-Qur'an and TP al-Qur'an) since the 1980s and has slowly shifted the popularity of bagda>diyyah method. Although the students were required to be more active in this method, the teacher still has a central role in supervising the readings of students until they are truly fluent in reading the Qur'an. 
Broadly speaking, the Qur'anic learning system adopted by the Indonesian people from the 15 th century to the last half of the 20th century strongly emphasized the existence of direct interaction between teacher and student. During the learning process, a number of values and courtesies toward the Qur'an were applied by the teacher and students. Those manners were handed down from generation to generation and have become an orthodoxy value which was constantly held. Some of those values are that the teacher and student must be pure from h\}adas| during the process of learning the Qur'an, that the Qur'an must be carried by placing it on the chest or head, and that a teacher must ensure the reading of students is correct before proceeding to the next learning steps (al-Nawawi, 1999). So, the Qur'anic learning process did not necessarily mean that students can read the Qur'an correctly, but also to instill the value of politeness in the Qur'an as the holy book which is believed as the words (kala>m) of God.

The first half of the 21 st century was the starting point of the emergence of Qur'anic learning method which provided features and models that put forward the aspects of speed and effectiveness of learning. The need of the modern Muslim community for instant and pleasant learning of the Qur'an has opened promising market opportunities. Many Qur'anic learning books with an instant method appear in bookstores. A busy children's study schedule at school is one factor for parents (especially in urban areas) to buy their children instant Qur'an learning books, without the need to put them in the Qur'an Education Institution. This condition has gradually shifted the role of the Qur'anic educational institutions. Among the methods that emerged at this time were the hanifida method, the yanbu'a method, the as-syafi'i method, the muri method, the Qur'an finger method, and the tilawati method. All of them are unique, yet have the same goal, namely that students are able to read the Qur'an quickly and instantly. The convenience for convenience offered by these methods allows the user to learn the Qur'an by self-taught. This of course can slowly distort the orthodoxy values (manners and etiquette) that have been held by the teacher and students when the learning of the Qur'an takes place, as found in the previous methods. However, many of the new methods are learned through direct guidance from a teacher. 


\section{DIGITAL BASED LEARNING APPLICATION ON PLAY STORE}

The emergence of software-based application of Al-Qur'an learning is a logical consequence of the needs of modern society for instant matters. The great market opportunity to provide the application of learning the Qur'an makes many application activists in the country competing to develop it. Among the many applications available, there are two applications in Play Store that are the most downloaded and at the same time will be the object of research in this paper. The two applications will be explained as follows:

\section{Marbel Belajar Mengaji Application}

Application Details:

- Version: 3.2 .8

- Initial Release: October 31, 2019

- Last Update: May 27, 2019

- Number of Downloads: 1000,000 + downloads

- Offered by: Educa Studio

Marbel Belajar Mengaji is an Education application wich targeted at 3-8 years old children. This application helps children learn to recognize hija > 'iyyah letters, learn to read hija> 'iyyah letters with the $h\{$ araka $>t$, and learn to read hija > 'iyyah letters with tanwi $>n$. This application is also equipped with a number of supporting narratives that can facilitate children in learning, such as pictures, sound narration, animation, and various games. This application is equipped with 5 learning packages, namely (the Hijaiyah Letters Learning package), the Harokat Learning package, the Tanwin Learning package, and the Iqro' Learning package. The game packages provided include Quiz of Guessing Pictures of Hijaiyah Letters), Hijaiyah Letters Puzzles, Write Hijaiyah Letters, Guess Harokat and Tanwin, and Fish Hijaiyah Letters. In addition, Marbel Belajar Mengaji application is equipped with 2 choices of languages, Indonesian and English.

Overall, this application has four main menus, namely Daily Prizes, Main Page, Learning Menu, and Play Menu. Daily Prizes is the menu that first appears when the 
application is opened by the user. The Daily Rewards menu allows users to get bonuses in the form of stars. Whereas the Main Page contains selected items with various color variants. In addition to color, the main menu is also equipped with a back sound in the form of musical instruments and guide sounds. The Learning Menu contains four learning items, namely recognizing hijaiyah letters, knowing harakat, knowing tanwin, and knowing iqro'. All learning items contain the same principles, which are both presented with pictures (cartoons), various colors, music, and guide sounds. The Playing menu provides five types of games that allow users to recognize hija > iyyah letters quickly and precisely, among them fast-paced games, puzzles, writing, guessing, and fishing for hija > 'iyyah. Every game that is answered correctly will be given a reward.

\section{Belajar Mengaji Al-Qur'an Application}

Application Details:

- Version: 3.1.3

- Initial Release: July 5, 2014

- Updated on: March 29, 2019

- Number of Downloads: 1000,000+ downloads

- Offered by: iMajlis Mobile

Belajar Mengaji Al-Qur'an Application is equipped with a number of learning materials such as hija 'iyyah letters, iqra', short vocals, tajwi >d and tanwi>n, suku>n, madd, syaddah, memorizing short letters with audio, and 114 of Qur'anic chapters.

This application is filled with varied colors in each learning material. In addition there are also audio options that allow users to listen to the sound (pronunciation) of a word or sentence in hija 'iyyah letters. Another uniqueness that is served by this application lies in the complexity of the learning. There are groupings of learning from class A to class $\mathrm{H}$, where each class consists of material and examples of short letters. So its users can immediately apply learning material through the sample letters presented. 
From the brief description of the application of Marbel Belajar Mengaji and Belajar Mengaji Al-Qur'an, I found a number of important points that can be assumed as factors that make these two applications get the most downloads in the Play Store, they are:

First, both of these applications provide features that touch three aspects of learning at once, namely visual (visual), auditory (auditory), and kinesthetic (practical) aspects. The visual aspect allows people who learn to understand objects with the help of vision, such as by observing images and color variants. The auditory aspect is a person's ability to capture information through hearing, such as listening to music and sound, while the kinesthetic aspect is one's ability to understand something by practicing it directly, such as touching and moving an object (Gilakjani, 2012).

Secondly, this application both has a fairly complete learning package. The material presented is arranged from the easiest level (introduction to hija > 'iyyah letters and various punctuation marks) to the highest level (the ability to read one sentence or verse). Even so, the application of Belajar Mengaji Al-Qur'an is somewhat more complete because it immediately offers the practice of learning to use short letters in the Qur'an, where Marbel Belajar Mengaji application is only limited to using material from Iqra'.

Thirdly, both of these applications do not encourage the supervision of a teacher or parent of children who will use them. Anyone can use this application self-taught.

QUR'ANIC LEARNING SOFTWARE IN PLAY STORE: AN EFFECTIVE LEARNING VIS A VIS THREATS TOWARD ORTHODOXY OF THE QUR'AN

The Qur'anic learning based on software has become a logical consequence of technological acceleration and the urgent needs of society in the modern era. The massive dependence of the community in the use of gadgets is made fertile ground by some people to create digital applications, including learning the Qur'an. The emergence of Qur'anic learning applications has increased the interest of the community (especially children) in Indonesia to learn about how to read the Qur'an. This fact can 
be evidenced by the number of downloads obtained by the two applications on Play Store which reached more than one million downloads.

From the psychological side, there are many positive impacts resulting from software-based learning of the Qur'an. Among them is that learning done feels more fun because it is served with a visual appearance that stimulates children's interest to learn to read the Qur'an, as demonstrated by the application of Marbel Belajar Mengaji and Belajar Mengaji Al-Qur'an. The success of these applications can also be seen in terms of the effectiveness of learning, where the two are able to summarize three aspects of learning at once, namely visual, auditory, and kinesthetic. With this concept of "learning by playing", the children may not feel bored to continue to hone his ability to understand hija > 'iyyah letters until they are finally able to read verses of the Qur'an. Not only children, teenagers to adults are also possible to be interested in Qur'anic learning software because of its complexity.

Apart from the positive values it offers, the presence of Al-Qur'an learning software can threaten the value of Qur'anic orthodoxy that has evolved in society for centuries. The strong interaction between teacher and student is the most important component in the traditional Qur'anic learning process, where this kind of thing is not found in software-based learning. This is reinforced by the existence of the term Qur'anic recitation which comes from the word "al-talaqqi> " (meeting), which requires a meeting between the teacher and students when the learning process of the Qur'an takes place. The necessity to meet between teacher and student was built on the purpose of perfect pronunciation of the letter by letter of the Qur'an as he was received through the path of sanad which continued to the Prophet Muhammad (Shaleh, 2010). That is why in traditional Qur'anic learning a teacher might not give an opportunity for his student to move to the next stage before the student is truly fluent and in accordance with what is taught by the teacher. This kind of orthodoxy is a "missing aspect" of software-based learning of the Qur'an because there is no direct interaction between a teacher and student. It can even be said that the protective value of students in order to avoid reading errors is completely absent, so mistakes in reciting the Qur'an will be very vulnerable to occur. 
In addition, there are also philosophical values that are believed to exist only in the traditional Qur'anic learning tradition and cannot be found in the software-based process of learning the Qur'an. For example, in the tradition of traditional al-Qur'an teaching, there are two things that are always used by students in helping learning the Qur'an, namely suding and rehal. Both of these objects have their own orthodoxy values. In his book Tradisi al-Qur'an di Pesisir, Barir revealed that a number of traditional Muslim societies believe rehal as an ark that will be climbed by the reader of the Qur'an and suding as oars. Both objects are believed to be vehicles that will take them to heaven. The symbol is used by traditional society as a persuasive media to attract children to be enthusiastic in learning the Qur'an (Barir, 2017). The existence of orthodoxy about rehal and suding along with the symbols behind their use can be threatened by the emergence of software-based Qur'anic learning. Because when the software-based learning process is carried out by its users, they don't need any pointing devices (suhil) or tables (rehal), they can even put their gadgets anywhere they want.

Another orthodoxy value that can be threatened by the emergence of Al-Qur'an learning software is about the intensity of the use of al-Qur'an manuscripts along with the manners and etiquette directed at it. The use of al-Qur'an script in the process of learning the Qur'an in traditional times is something that is very essential. Every student is obliged to bring the manuscript of the Qur'an to the place of study while also paying attention to a number of etiquettes to the Qur'an, such as by performing ablution (washing) before touching it, putting it on the chest while walking, and not putting it under the knee while reading. Such values certainly will not (or at least rarely) be found in software-based Qur'anic learning. Apart from the absence of any suggestion or order to pay attention to these values, the manuscript of the Qur'an which are believed to be sacred for centuries are no longer considered important because they have been replaced by verses presented in digital form. It is not impossible that adolescents using the Qur'an learning application will no longer know the manners that must be given to the Qur'an because the Qur'an they used has been replaced by software-based devices.

\section{CONCLUSIONS (خلاصة |خاتمة)}

Friction between religious orthodoxy and technological advances in the modern era has always been a "hot" topic to discuss among academics today. The existence of religion that emphasizes a lot on the inner aspects and the existence of 
technology that emphasizes more on the physical aspects makes them often not go in the same direction. The presence of Qur'anic learning software is one of these cases. Even though it offers an effective and fast learning method, a number of orthodoxy values regarding the sacredness of the Qur'an and manners addressed by the Muslim community towards it for centuries have been threatened by the presence of Qur'anic learning software. Among these threats are aspects of the interaction that exists between teacher and student, the etiquette of the Qur'an, and the entity's use of the Qur'an's Manuscripts as learning media.

\section{BIBILIOGRAPHY (قائمة المراجع)}

\section{References :}

Ahmed, Shahab. Before Orthodoxy: The Satanic Verses in Early Islam. Cambridge and London: Harvard University Press. 2017.

Azra, Azyumardi. Pendidikan Islam: Tradisi dan Modernisasi menuju Milenium Baru. Ciputat: PT Logos Wacana Ilmu. 1999.

Barir, Muhammad. Tradisi al-Qur'an di Pesisir: Jaringan Kiai dalam Transmisi Tradisi al-Qur'an di Gerbang Islam Tanah Jawa. Yogyakarta: Nurmahera. 2017.

Dhofier, Zamakhsyari. Tradisi Pesantren: Studi tentang Pandangan Hidup Kyai. Jakarta: LP3ES. 1985.

Dhofier, Zamakhsyari. Tradisi Pesantren: Studi tentang Pandangan Hidup Kyai. Jakarta: LP3ES. 2011.

Gilakjani, Abbas Pourhossein. "Visual, Auditory, Kinaesthetic Learning Styles and Their Impacts on English Language Teaching". Journal of Studies in Education. Vol. 2. No. 1. 2012.

Gusmian, Islah. "Karakteristik Naskah Terjemahan Al-Qur'an Pegon Koleksi Perpustakaan Masjid Agung Surakarta” dalam Jurnal Suhuf. Vol. 5, No. 1. 2012.

Hasanah, Ulfatun Hasanah. "Pesantren dan Transmisi Keilmuan Islam MelayuNusantara; Literasi, Teks, Kitab dan Sanad Keilmuan". Dalam Jurnal 'Anil Islam. Vol. 8. No. 2. Desember 2015.

https://en.m.wikipedia.org/wiki/Google_Play

https://play.google.com/store/apps/details?id.imajlismobile.belajarmengajialquran

https://play.google.com/store/apps/details?id=com.educastudio.marbelmengaji

Muhammedi. "Metode Baghdadiyah (Metode Pembelajaran yang Efektif dalam Menanamkan Sikap Religius Siswa dan Meningkatkan Hasil Belajar Pendidikan Agama Islam) dalam Jurnal Al-Fatih: Jurnal Pendidikan dan Keislaman. Vol. 1. No. 1. Januari-Juni 2018.

Nawa>wi>, Abu> Zakariyya> al-. Al-Tibya>n fi> Ada>b H\{amalah al-Qur'a>n. Bairu>t: Da>r Ibn H\{azm. 1996.

Qomar, Mujamil. Pesantren Dari Transformasi Metodologi Menuju Demokratisasi Institusi. Jakarta: Erlangga. 2002. 
Sanjaya, Wina. Perencanaan dan Desain Sistem Pembelajaran. Jakarta: Kencana Prenada Media Group. 2010.

Shaleh, Iceu. "Ta'lim Qira'at al-Qur'an bi al-Tariqah al-Bagdadiyyah fi Qaryati

"Gorowong" Parungpanjang Jawa al-Garbiyyah" dalam Skripsi Fakultas Ilmu Tarbiyah dan Keguruan UIN Syarif Hidayatullah Jakarta. 2010. 